\title{
TEACHER TEAMS AND SCHOOLS BECOME LEADERS TO DISSEMINATE INNOVATIVE PRACTICE ${ }^{1}$
}

\author{
Dace Namsone \\ Līga Čakāne \\ Dina Sarceviča - Kalviške \\ University of Latvia, Latvia
}

\begin{abstract}
We will introduce a study about teachers taking part in networking for personal development and becoming teacher leaders. In 2011 a multilevel national joint collaboration network of schools with innovative experience was created to foster dissemination of new teaching and learning experiences among teachers. In order to organize learning for teachers, a lesson based collaborative continuous teacher professional learning model was implemented. The research shows that conducting and analyzing lessons has helped participants become more competent professionals and develop skills that are crucial for a good leader. Categories characterizing teacher leaders and lead schools were identified. Factors that facilitate or limit teachers or schools to become leaders are discussed.
\end{abstract}

Keywords: collaboration network of schools, lesson based collaborative continuous teacher professional learning, teacher leader.

\section{Introduction}

The key focus of the new curriculum introduced in Latvia in 2016 lies on the transition to a competency based learning. This means that teachers will have to implement change from the current paradigm of mastering multiple new strategies of organizing and leading teaching to immersion in their own practices. Previous research on the reforms introduced in 2006 revealed that changes enter the classroom at a very slow pace (France et al., 2015; Volkinsteine et al., 2014). The process of changing the paradigm highlights the following problem: how can innovative experience of teaching and learning be disseminated further? Implementation of the new practice calls for professional, innovative teachers who are qualified and willing to share with their colleagues. Fullan's (1991) definition of teacher leaders: "The ability of a person to bring about changes among teachers and teaching" describes important leadership qualities. However, a single highly professional and motivated teacher is not enough for the changes to occur faster and persist over time. The school needs a

\footnotetext{
${ }^{1}$ This research is supported by National Research Program Project VPP 2014-2017

(C) Rēzeknes Tehnologiju akadèmija, 2016

DOI: http://dx.doi.org/10.17770/sie2016vol2.1393
} 
community of teachers that are willing to face, implement and reflect on the changes (Hargreaves \& Fullan, 2012).

\section{Teacher learning organization}

According to Van Driel et al. (2001) practical theories that guide teachers in teaching are based on practical knowledge. Teachers' practical knowledge is constructed by the teachers in the context of their work integrating experimental knowledge, formal knowledge and personal beliefs. Teachers acquired formal knowledge at the university and in-service training. In a previous study (Namsone et al., 2015) we described that traditionally a science subject teacher was educated as a teacher of a single subject (chemistry, physics, biology) and acquired a science based program (up to $90 \%$ subjects focused on covering science subject content) in Latvia. Moreover, for a number of years teacher inservice training was mostly organized as a transmission of new information. Schools usually employ only one teacher of physics, chemistry or biology and the exchange of experience among them or between schools is poor or focuses mainly on delivery of new information. As a result, many teachers' beliefs and practical knowledge are limited to their personal practical experience or the manner of how they were taught at school.

In order to make changes happen, teachers have to be immersed in their own and their colleagues' practice during training, analyzing and reflecting on it. It is crucial to create learning situations that allow teachers to acquire different kinds of experience, take part in discussions, exchange opinions, practice, analyze and reflect on their own and their colleagues' learning, that is, facilitate immersion. Previous research shows that teachers in Latvia fail to see the need to develop their analysis and reflection skills; teachers lack an opinion regarding the necessity of these skills and do not see them as part of their professional competences (Namsone \& Cakane, 2014; Namsone et al., 2015; France et al., 2015).

Work within EC FP7 Science in Society program PROFILES (Professional Reflection Oriented Focus on Inquiry-based Learning and Education through Science) project helped us to see the effectiveness of PROFILES continuous professional development (CPD) principles. The PROFILES project has triggered substantial discussion regarding promotion of inquiry-based science education by enhancing the science teachers' self-efficacy and sense of ownership. The key goals of the PROFILES CPD approach are to develop teachers professionally, based on the concept of a teacher as a learner, as an effective teacher, as a reflective practitioner (who strives to enhance other teachers' self-efficacy and ownership) and eventually, in some cases, as a leader (Hofstein \& Mamlok-Naaman, 2014). 


\section{Previous experience from teacher learning through collaboration}

In the western world different teacher collaboration groups and networks have been operating at least since the 1980's. Latvia took the first steps in this field quite recently. A successful teacher learning model was developed during the national development project 'Science and Mathematics" $(2009-2011)$, where teams of science and mathematics teachers learned together. The idea is that well developed teamwork improves the quality of practices as teachers work and learn from each other (Fullan, 2011). Collaboration within this model was organized as sharing (materials \& teaching strategies) and joint work - where teachers teach, plan or inquire into teaching together. In 2011 there was a clear need to seek alternative ways of facilitating dissemination of the new teaching approach, ideas and changes, and sustain the progress achieved during the previous projects.

The need to develop lead schools for dissemination of new teaching and learning experience among other teachers became obvious. Consequently, a national joint collaboration network of schools with innovative experience was established under the National Center for Education (NCE) and the Center for Science and Mathematics Education (CSME) at the University of Latvia. The goal was to create schools where teachers are willing to open doors of their classrooms and share their experience of planning and leading lessons by demonstrating the new approach. This would enable other teachers to see a different way of teaching and to discuss their observations during lessons, which would encourage teachers to incorporate the new practice into their own classrooms.

A joint collaboration network was created as a multi-level model that acts on the national, municipality and school level involving teachers, school management and coaches from CSME. Each national network school has a team (4-5 people) of science subjects and mathematics teachers (one of each subject) and a school deputy head. On the municipality level, each school is attached to a network of schools based on their location. At the beginning of the school year of 2011/2012, according to the local needs and in collaboration with the local municipality each school reached out and invited teachers of science subjects and mathematics as well as the school management representatives from the respective municipality. This was a new form of work for the municipalities because previously the operating hierarchical model was based on teachers' methodological associations with a municipality's appointed person at the head. 


\section{The developed teacher learning model with in the network}

If we want to train teachers to collaborate among themselves, we must first address their skills of acting as "agents of change" i.e. leaders disseminating innovative experience. A continuous professional learning model (PLM) for teachers with an emphasis on teacher collaboration for professional learning was developed within the teacher collaboration network. The developed PLM focuses on joint observation in a real-life classroom environment and lesson analyses. The model consists of a set of regular workshops over the period of a school year. It is based on the philosophy that change arises from a teacher's immersion in one's own and his/her colleagues' practice. It is facilitated by regular trainings of reflection skills and repeating the immersion cycle "observe - reflect - write - discuss" as in the action research (AR) spiral (Kemmis \& McTaggart, 2000) conducted a few times during every workshop and multiple times during the whole cycle of workshops.

This research poses following questions:

- What skills have teachers developed through experience acquired from participation in the collaboration network and CPD developed?

- What are the characteristic categories of teacher leaders and schools that actively participate in the national joint collaboration network after intervention?

- What are the main factors that help teachers and schools become real leaders?

\section{Methodology of the Research}

\section{Description of the participants involved in the network}

The national network includes teacher teams from 22 schools representing 19 municipalities all over Latvia, from both urban and rural schools, 6 basic education schools and 16 secondary schools ( 3 of them with a minority language of learning). The total of the participants in the national network amounts to 82 teachers and 22 school management representatives. The national network was formed from the teams of schools that already had experience in the piloting of the new curriculum within the project 'Science and Mathematics' and who had acquired a practice based professional development program of 160 lessons. A more detailed description has been given to reveal the skill and performance of school X- rural secondary school (number of students in 1-12 grades about 340, teachers-34). The school team consists of 4 teachers and the school deputy head. A total of 480 teachers from 149 schools were involved in municipality level networking beginning in the school year 2011/2012. 
Coaches from CSME (8 people with expert and coaching experience of 5 15 years) led workshops, provided feedback to the participants and developed the research. Coaches are required to be well trained and prepared to conduct video trainings, multiple live lesson observations, jointly analysed lessons, focus group discussions before and after each seminar, as well as regular individual lesson observation trainings.

\section{How the PLM operates within the network}

The professional development program (80 lessons over two study years) included input sessions on a particular issue (effectiveness of learning, scientific inquiry etc.), a real-life observation of lessons with joint lesson analysis and reflection sessions. Teacher learning is organized within the network of a regional group. One regional group included 5 - 6 schools from a national network. During two school years from November 2011 through April 2013 participants took part in two cycles of 5 workshops, each of them in a different school. The length of one workshop is 8 sessions (40 minutes each). Involvement enabled every participant to experience afew roles: to lead an open lesson for colleagues (as a leader) and to be a learner and a reflective practitioner- learn to observe, analyze and reflect about their colleague teaching and student learning practices.

With the multi-level collaboration network and the teacher PLM implemented within the national network, teachers will engage in a more extensive self-educating process (including leadership skills) on the municipality level network, and afterwards the municipality level practice will measure the acquired leadership skills in action. School and teacher leadership will be manifested through the school team applying the acquired ideas in the local network, sharing experience with regional schools, and transferring the experience from the national network to the school as a whole.

Forms of work and the number of involved schools and teachers differ. The school team jointly plans, implements and evaluates different activities for further development and dissemination of the ideas of innovative sciences education among other teachers. Network members share mutual trust and support, learn together through workshops and seminars, exchange of study aids, leading and mutually observing lessons, etc. The municipal network horizontally involves a large number of teachers who learn from each other, exchange experience in real-life settings at school and focus on the lesson.

\section{Sources for data collection}

The following data will help to describes kills and performance of school teams and teachers, to identify the typical manner of performance, qualities, 
attitudes, categories and to describe them in the respective levels where each level has obvious qualitative differences:

1. The impact of the network and CPD developed (period 2011-2013) was analyzed through teacher questionnaires issued after the first and second year of the network (2012, 74 respondents) and (2013, 82 respondents). Each questionnaire is analyzed for credibility. $\mathrm{R}$ version 3.1.1 is used.

Each survey included questions about teacher skills to conduct teaching and learning, teacher's own performance and reflection, including leadership skills, factors facilitating professional training and growth, as well as support needs. Respondents evaluated different aspects and effects of the collaboration model and specified the acquired benefits. For example, 6 questions in each survey covered reflections from joint analyses of the observed lessons. Evaluation was made according to the Likert scale $(0-$ the skill has definitely not improved, 5 - the skill has significantly improved). Respondents were also invited to provide comments to support their answers. Additionally, the survey from 2013 required teachers to evaluate the impact of each level of the network on their professional growth.

2. Written feedback from teachers after workshops - participants provided written feedback (answers to the same questions: benefits from lesson observation and from lesson analyses at the end of each seminar). The feedback was coded for the purposes of analyses.

3. Teacher focus group discussions which were documented, coded and analyzed.

4. Documentation of the performance of school teams.

5. Structured interviews of school administration.

6. Transcripts from coaches' focus group discussions - made after each seminar; coaches' oral feedback and written transcripts of seminars.

\section{Results and Discussion}

\section{What skills did teachers improve in network and CPD developed?}

According to the teacher survey (2012, Cronbach's alpha 0.87 and 2013, Cronbach's alpha 0.94) teachers indicate that leading and analyzing lessons has helped them to become a more competent professionals and to acquire the skills and assurance that are crucial for a good leader. Data from surveys show the percentage of respondents that gave the highest evaluation 5 to the respective statement.

Teachers have improved their teaching skills (as a teacher) -to plan and lead an effective lesson (68 \%) and to professionally apply teaching and assessment skills (52\%). Teacher comments reveal the following: "Lesson 
planning, modelling and seeking answers as well as answering to the question why this activity must be included in the lesson and how it will lead to achieve the outcome had the largest contribution to my understanding of organization of effective learning in the lesson". Coaches' transcripts confirm improvement of skills, for example: "Teachers have learned to choose effective way of achieving the outcome, to clarify every step of the lesson, to provide feedback to students and plan development of student self-evaluation skills". Table 1 summarizes data regarding improvement of teacher as reflective practitioner skills.

Table 1 Teacher skills to analyze and reflect on their practice

\begin{tabular}{|c|c|c|}
\hline Category & Teacher skills & $\begin{array}{l}\% \text { of } \\
\text { respondents }\end{array}$ \\
\hline \multirow{2}{*}{$\begin{array}{l}\text { Analyze } \\
\text { their } \\
\text { practice }\end{array}$} & Evaluate their performance & 43 \\
\hline & $\begin{array}{l}\text { Have developed a need for immersion in their professional } \\
\text { performance }\end{array}$ & 77 \\
\hline \multirow{4}{*}{$\begin{array}{l}\text { Reflect } \\
\text { together } \\
\text { with } \\
\text { colleagues }\end{array}$} & Receive feedback & 46 \\
\hline & Observe and analyze the lesson & 69 \\
\hline & $\begin{array}{l}\text { Reflect on the idea and effectiveness of the lesson with their } \\
\text { colleagues }\end{array}$ & 59 \\
\hline & Provide feedback and recommendations & 28 \\
\hline
\end{tabular}

Teachers shared the following comments describing their professional growth in the area of analysis, reflection and collaboration with colleagues: "I was learning to distinguish what I really know and am able to do from what I thought I knew (I assumed)". During interviews school deputy heads admitted that: "It is not enough for a teacher to see and hear new things - they have to be discussed with a focus on how we can apply the experience, try it out and demonstrate it to others. Discussion facilitates our professional capability". Coaches' transcripts reveal the level of teachers' skills and their willingness to immerse themselves in the experience, for example: "Teachers make conclusions based on particular facts encountered during the lesson. They are better at acknowledging success and aspects to be improved". Deeper analyses on reflection skills can be found in the following source (Namsone et al., 2015).

$45 \%$ of teachers from the survey admit improvement of their readiness to share ideas and experience; $52 \%$ point out the development of common values (teaching philosophy) and ownership which contributes to the development of a teacher as a leader skills. However, leadership was not addressed as a primary goal of learning. Many teachers have never been exposed to leadership training, and they have to "break out" of their past practices, because opening of the classroom door to their colleagues has not been a common tradition in their work. Although the survey from 2013 shows that only $8 \%$ of teachers expressed 
willingness to lead, in several cases their performance already demonstrated a strong presence of leadership skills. According to teacher A: "A heated discussion broke out during analysis of a lesson. At the beginning I got extremely confused - how do I resolve this situation? However, I was able to concentrate and lead the discussion successfully. It was a great experience to learn how to lead any process in the desired direction towards a set goal (in the classroom and collaborating with other teachers)'.School deputy heads admit that: "Teachers have overcome their fear of seeing observers in their lessons because the follow up discussions are conducted in a professional manner and each party is open to learn. Teacher improvement is enormous! From "ordinary teachers" they have turned into confident classroom leaders with authority on the school and regional level".

\section{Characteristic categories of teacher leaders and schools}

Scholarship on teacher leadership proves that among the many functions that teacher leaders can have, facilitating professional learning communities is one of them. Teacher leadership stems from their successful work in the classrooms helping teacher leaders gain respect and trust from their colleagues. Through trustful relationships teacher leaders extend their knowledge and skills to other teachers (York-Barr \& Duke, 2004). In our study we looked closer at how teacher leaders work and how they contribute to their schools becoming lead schools.

Analyses covered the typical demonstration of the skills and activities of school teams, with their qualities, attitudes and categories singled out to describe teacher leaders, focusing on the changes in the lesson and on dissemination of innovative practices among other teachers (see Table 2). During analysis of teacher leader activity in different schools, and to define teacher leaders, each of the descriptors of categories is viewed on the respective level according to the scale $1-3$, where $1=$ sometimes, $2=$ often, $3=$ regularly. The example shows activity of a teacher leader team in school $\mathrm{X}$, where their evaluation against descriptors is the highest in a large part of the criteria.

Analyses of the data about schools suggest defined categories that describe lead schools (see Table 3). Examining of lead schools, each of the category descriptors is viewed in levels on a scale 1-3. A high level (most criteria corresponds to a level 3) teacher team and school as a whole is the focus of example X. 
Table 2 Categories describing a teacher leader

\begin{tabular}{|c|c|c|}
\hline Categories & Descriptors & Evidence about school X \\
\hline \multirow[t]{2}{*}{ Ownership } & $\begin{array}{l}\text { Uses appropriate approach and } \\
\text { strategies in practice in the } \\
\text { lessons. }\end{array}$ & Lesson observation data. \\
\hline & $\begin{array}{l}\text { Develops new materials and } \\
\text { examples according to the new } \\
\text { idea. }\end{array}$ & $\begin{array}{l}\text { The developed new teaching materials } \\
\text { within the PROFILES project; NRP *. }\end{array}$ \\
\hline \multirow{2}{*}{$\begin{array}{l}\text { Continuous } \\
\text { professional } \\
\text { learning }\end{array}$} & $\begin{array}{l}\text { Gets involved in long term } \\
\text { learning teams. }\end{array}$ & \multirow{2}{*}{$\begin{array}{l}\text { All } 4 \text { teachers got involved in AR groups } \\
\text { with CSME, the deputy head - in school } \\
\text { management AR group in the first year of } \\
\text { its work (2011). }\end{array}$} \\
\hline & $\begin{array}{l}\text { Gets involved in practical } \\
\text { studies targeted towards } \\
\text { immersion. }\end{array}$ & \\
\hline \multirow{2}{*}{$\begin{array}{l}\text { Regularly } \\
\text { analyzes their } \\
\text { performance } \\
\text { and reflects } \\
\text { on it }\end{array}$} & $\begin{array}{l}\text { Accepts feedback and reflects } \\
\text { on their performance. }\end{array}$ & $\begin{array}{l}\text { High level analysis and reflection skills in } \\
\text { written feedback etc. }\end{array}$ \\
\hline & $\begin{array}{l}\text { Takes active participation in } \\
\text { AR etc. groups. }\end{array}$ & $\begin{array}{l}\text { Active participation in discussions in } \\
\text { working groups about the developed } \\
\text { samples, in AR groups. }\end{array}$ \\
\hline \multirow[t]{2}{*}{$\begin{array}{l}\text { Readiness to } \\
\text { share, } \\
\text { openness }\end{array}$} & $\begin{array}{l}\text { Invites colleagues to their } \\
\text { lessons for observation and } \\
\text { analyses. }\end{array}$ & $\begin{array}{l}\text { Mutual lesson observation at the school } \\
\text { commenced in 2011/2012. Teachers from } \\
\text { other schools are invited to join lesson } \\
\text { observation analyses regularly. }\end{array}$ \\
\hline & $\begin{array}{l}\text { Leads workshops, gives } \\
\text { presentations etc. outside the } \\
\text { school. }\end{array}$ & $\begin{array}{l}\text { Participation with AR project outcomes in } \\
\text { follow up conferences and national annual } \\
\text { teachers' conferences. }\end{array}$ \\
\hline Teamwork & $\begin{array}{l}\text { Jointly plans, analyses, } \\
\text { organizes and evaluates. }\end{array}$ & $\begin{array}{l}\text { Jointly planned lessons within the } \\
\text { collaboration, joint lesson observation and } \\
\text { analyses, follow-up conference at the } \\
\text { school. }\end{array}$ \\
\hline $\begin{array}{l}\text { Takes } \\
\text { initiative to } \\
\text { lead activities }\end{array}$ & $\begin{array}{l}\text { Initiates and organizes regular } \\
\text { teacher learning } \\
\text { activities at the school and the } \\
\text { region }\end{array}$ & $\begin{array}{l}\text { A total of } 5 \text { AR groups included } 26 \\
\text { teachers of different subject matters since } \\
\text { 2012; leading AR groups on the } \\
\text { municipality level since } 2014 .\end{array}$ \\
\hline $\begin{array}{l}\text { Self- } \\
\text { awareness, } \\
\text { confidence }\end{array}$ & $\begin{array}{l}\text { Demonstrates respect to } \\
\text { colleagues' feedback. }\end{array}$ & $\begin{array}{l}\text { Proactively seeks feedback from } \\
\text { colleagues and CSME coaches. }\end{array}$ \\
\hline
\end{tabular}

*In 2014 CSME established a specific group of NRP inviting 3 teachers out of 4. The observed professional growth and ownership allowed the 4th colleague to join the team the following year. 
Dace Namsone, Līga Čakāne, Dina Sarceviča - Kalviške. Teacher Teams and Schools Become Leaders to Disseminate Innovative Practice

Table 3 Categories describing a lead school

\begin{tabular}{|c|c|c|}
\hline Categories & Descriptors & Examples, evidence (school X) \\
\hline \multirow[t]{4}{*}{$\begin{array}{l}\text { Learning } \\
\text { community }\end{array}$} & Learning is purposeful & $\begin{array}{l}\text { Training for entire staff of teachers "Effective } \\
\text { lesson", "Feedback" etc. since } 2011 .\end{array}$ \\
\hline & Learning is effective & $\begin{array}{l}\text { Since } 2012 \text { the school has had AR groups; since } \\
2011 \text { - mutual lesson observation and analyses. }\end{array}$ \\
\hline & $\begin{array}{l}\text { Learning is regular, } \\
\text { continuous }\end{array}$ & $\begin{array}{l}\text { Organizes monthly meetings of AR groups and a } \\
\text { follow-up conference. Every semester provides } \\
\text { training workshops. }\end{array}$ \\
\hline & $\begin{array}{l}\text { Involvement of most } \\
\text { teachers }\end{array}$ & $\begin{array}{l}26 \text { teachers (from } 34) \text { participate in AR groups; } \\
\text { workshops are organized for all teachers. }\end{array}$ \\
\hline \multirow[t]{2}{*}{$\begin{array}{l}\text { Collaborativ } \\
\text { e school. }\end{array}$} & $\begin{array}{l}\text { Collaboration is } \\
\text { purposeful }\end{array}$ & $\begin{array}{l}\text { Collaboration between colleagues focused for } \\
\text { improvements, innovation, or implementation of } \\
\text { changes. }\end{array}$ \\
\hline & $\begin{array}{l}\text { Collaboration is } \\
\text { inclusive, with } \\
\text { tendency to expansion }\end{array}$ & $\begin{array}{l}\text { Collaboration started in a team of } 5 \text {; now includes } \\
26 \text { colleagues. }\end{array}$ \\
\hline \multirow[t]{2}{*}{$\begin{array}{l}\text { Initiative to } \\
\text { share } \\
\text { experience }\end{array}$} & $\begin{array}{l}\text { Welcomes colleagues, } \\
\text { organizes events }\end{array}$ & $\begin{array}{l}\text { The local network of school } X \text { involves } 7 \text { schools; } \\
\text { has been providing exchange of experience since } \\
2011 / 12 \text {. }\end{array}$ \\
\hline & $\begin{array}{l}\text { Organizes workshops } \\
\text { with lesson observation } \\
\text { and analysis for } \\
\text { colleagues from other } \\
\text { schools. }\end{array}$ & $\begin{array}{l}\text { Hosted and lead } 1 \text { international (Ecobalt 2014), } 11 \\
\text { national level and } 24 \text { municipality level workshops } \\
(2011-2013) \text {. }\end{array}$ \\
\hline
\end{tabular}

Analysis of the activities performed by schools, school teams and teachers show differences that testify to an understanding of the significance and purposefulness of CPD. The data clearly shows the difference in leadership levels, for example, presence of experience to form focused, continuous (level 3) learning activities at the school and getting involved in this kind of activities outside the school. A deputy head: We are learning to open the classroom door, to reflect and not to be afraid if we make mistakes. We will continue to practice joint learning, collaboration lessons, observation, analyses and joint lesson leadership. We will reflect and discuss teacher progress in organizing learning in the classroom. We are certain that $10 \%$ of teacher work time must be 
allocated to efficient professional training. This reflects other research findings regarding teachers' professional development (Barber \& Mourshed, 2007). However, a contrasting kind of experience is also encountered - some schools offer short level separate activities with uncorrelated content.

Schools organize events for their counterparts transmitting not only the acquired ideas but often also the learning format. The involved schools are providing workshops with lesson leading and observation, joint planning, etc.

Evaluations by the municipality level participants evidence progress. After the first year (2012) a teacher from a region X school wrote the following: "At first, participation in the school collaboration project made me feel like a cricket that has fallen in hot ashes. However, I acquired a lot of professional experience "tricks" and ideas. I was feeling like a student before an exam, and I did not enjoy having to lead the lessons. However, I would like the collaboration to continue". After two years of work (May 2013, school survey) the following views prevail: I could acquire new nuances of how to guide learning most efficiently - the key factor is economy of time combined with purposeful acquisition of the planned outcome. I saw examples of how to encourage students to think more about how learning is happening in the lesson, how to achieve and encourage student involvement, how to give positive evaluations and analyze the lessons, etc.

Teacher professional growth is also supported by coach's notes after leading a workshop at school X in May 2013: "The progress of the school X team is obvious! Teachers from regional schools had a discussion on a high professional level: they asked questions, were willing to immerse themselves in the essence of the process, identify causes of problems in the analyzed lessons and model solutions".

A school that gets involved in the network can become a center of a learning cluster for other schools. This is exactly what sources of literature say about a learning community and school clusters (Hargreaves \& Fullan, 2012).All network schools are working in a similar way to accomplish the transmission. Part of the network follows the model described above. We encountered schools whose reviews show a lot of activity in work with other schools. However, their efforts are of a campaign character and lack regularity and continuity (level 1). Some schools try to cover the entire range of activities but they fail to focus on the goal (level 1) and do not form continuous collaboration. 


\section{Contributing and limiting factors for teachers and schools to become leaders}

Analysis of the benefits reveal that the teacher CPD model operating in the regional groups of the national network has had the largest impact on the development of leadership skills. The model has fostered teaching skills in the classroom as well as the reflection skills, and has significantly improved teacher awareness of the need to immerse themselves in their professional performance.

Teacher activity, in its turn, in their own developed local network has had the largest impact on the improvement of lesson analysis and mutual collaboration skills. Teachers assign the biggest significance of the local network as a motivator for immersion in teacher performance and experience sharing.

School teams are described as the best facilitators for developing skills to provide feedback and recommendations to colleagues. Team work has facilitated readiness to share ideas and experience, form mutual trust, and experience the feeling of receiving the biggest support and shouldering from colleagues.

Teachers highlight the role of school management as a factor that has a significant impact on joint collaboration with colleagues. This corresponds to previous research on relationships between teachers and school management, where principals are regarded as playing an important role in supporting teacher leadership (for a review see York-Barr \& Duke, 2004). Results are better if school management work as real leaders of the learning process, support their teachers and facilitate team collaboration within the school. In the circumstances of Latvia, a direct, regular involvement of school management in the work of the school team and providing incentives turned out to be the key to success. Involvement of the management ensured joint understanding and immediate support. Schools that lack such involvement fail to reach a high level of leadership. Due to the soviet legacy when volunteering was often compulsory (a teacher suffered consequences from the management if he/she refused to volunteer), Latvia still carries a specific peculiarity - the initial involvement of teachers in the collaboration network is' voluntarily compulsory' rather than truly voluntary. This can be explained by the historical tradition in teacher education and school administration in the country (Rauch et al., 2014).Teachers' comments and interviews with school management highlight the significant role of the team in the initial stage of the activity and point to the team as a contributor or hindrance to the progress; teachers especially emphasize importance of the team in situations when teachers face misunderstanding and resistance from their colleagues. At the same time the school team has a decisive role in the entry and implementation of changes in the school on the whole, which allows the school to become a real leader among schools. A school 
deputy head states that: "Progress of the teacher network inspires other teachers to pursue their personal development".

Implementation of changes, acquisition of assurance and ownership takes time and a focused goal. School managers think likewise: "Continuous mutual experience exchange among teachers and piloting different teaching strategies create a lot more stable grounds for permanent changes".

The outcome depends on the teachers' own learning skills, his/her willingness to get involved, to develop and to balance the individual development needs with the goals and needs of the team. Changes happen if the teacher knows how to immerse him/herself in his/her own practice. In the case of a leader - if the teacher acquires ownership of the idea; if he/she accepts it and learns how to apply it in order to be ready to share the experience with others. A teacher from school X admitted the following: "Changes in thinking and attitude is the key. For it has been incredibly difficult to give up my old stereotypes. However, this year I have more or less succeeded to do that to some extent. It is my biggest benefit because I am not an optimist by nature, and I always tend to first see the negative, and only then I notice the positive. Together we learned to look at things differently. We learned to see the positive and this was a huge thing for me. If you see the positive, it lifts you up and gives you strength to accomplish just about anything”.

\section{Conclusions}

On the national level of the school collaboration network, teachers improve their teaching, reflection and collaboration skills, and this helps them gradually become leaders working with other teachers.

An experience exchange movement of regional character provides local teachers with new opportunities of acquiring learning experience through involvement in seminars with lesson observation and teacher collaboration groups.

Our experience of a high level teacher leader defines him/her as a teacher who regularly analyzes and reflects about his/her own practice; purposefully plans and addresses his/her professional development needs; constantly develops new teaching materials for evaluation and use for other teachers; opens the classroom door to colleagues for lesson observation; involves other colleagues in a joint learning process; collaborates with colleagues in jointly planning and developing activities within the school team; shares his/her experience in seminars and conferences on the school, municipality or national level.

A lead school is characterized by the presence of purposeful, effective, continuous learning activities attended by most teachers, regular teacher 
collaboration in implementation of changes, as well as initiative for regular organized experience exchange with teachers from other schools.

The main contributing factors are the following: operation of a network CPD model, success of the activities organized by the school, strength of the school team, support of the school management, time for continuity of activity and outcomes as well as teachers' personal qualities and experience.

Definition of network leadership qualities (a framework of categories and descriptors) is a crucial achievement of this study that will be an invaluable aid to implementation of the new competency based approach, leading to the development of a network of teacher leaders and lead schools that ensure effective implementation of planned reforms in all stages of education.

\section{References}

Barber, M. \& Mourshed, M. (2007). How the world's best performing school systems come out on top. McKinsey \& Co. Retrieved from http://www.smhc-cpre.org/wpcontent/uploads/ 2008/07/how-the-worlds-best-performing-school-systems-come-outon-top-sept-072.pdf

France, I., Namsone, D., \& Cakane, L. (2015). What Research Shows about Mathematics Teachers' Learning Needs: Experience from Latvia. In SOCIETY, INTEGRATION, EDUCATION. Proceedings of the International Scientific Conference (Vol. 2, pp. 45$55)$.

Fullan, M. G. (1991). New meaning of educational change. New York, NY: Teachers Colleague press.

Fullan, M. (2011). Whole System Reform for Innovative Teaching and Learning. In Innovative teaching and learning research. 2011 Findings and Implications. Retrieved from

http://www.itlresearch.com/images/stories/reports/ITL\%20Research\%202011\%20Findi ngs\%20and\%20Implications\%20-\%20Final.pdf

Hargreaves, A., \& Fullan, M. (2012). Professional capital: Transforming Teaching in Every School. New York, Toronto: Teachers Colleague Press; Ontario Prinipal's Council.

Hofstein, A., \& Mamlok-Naaman, R. (2014). Case Studies on PROFILES Teacher Training (CPD) and Ownership. In C. Bolte, J., Holbrook, R., \& Mamlok-Naaman, F. Rauch, (Eds.), Science Teachers' Continuous Professional Development in Europe. Case Studies from the PROFILES Project (pp. 161-164) .Berlin: FreieUniversität Berlin.

Kemmis, S., \& McTaggart, R. (2000). Participatory action research. In: N. Denzin, \& Y. Lincoln (Eds.), Handbook of Qualitative Research. London: SAGE.

Namsone, D. \& Cakane, L. (2014). National Networking of Teachers as a Tool for Dissemination of Innovative Teaching. In C. Bolte, J., Holbrook, R., \& MamlokNaaman, F. Rauch, (Eds.), Science Teachers Continuous Professional Development in Europe. Case Studies from the PROFILES Project (pp. 251-259). Berlin: FreieUniversität Berlin.

Namsone, D., Cakane, L., \& France, I. (2015). How science teachers learn to reflect by analyzing jointly observed lessons. LUMAT, 3 (2), 223-236. Retrieved from http://www.luma.fi/lumat-en/3854

Rauch, F., Dulle, M., Namsone, D., \& Gorghiu, G. (2014). PROFILES Networks: Three 
Proceedings of the International Scientific Conference. Volume II, May $27^{\text {th }}-28^{\text {th }}$, 2016. 208-222

International Examples. Science Education International, 25 (2), 97-114. Retrieved from http://www.icaseonline.net/sei/june2014/p5.pdf

Van Driel, J., Beijaard, D., \& Verloop, N. (2001). Professional development and reform in science education: the role of teachers' practical knowledge. Journal of Research in Science teaching, 38 (2), 137-158.

Volkinsteine, J., Namsone, D., \& Cakane, L. (2014). Latvian chemistry teachers' skills to organize student scientific inquiry. Problems of Education in the 21 st Century, 59, 8698.

York-Barr, J., \& Duke, K. (2004). What do we know about teacher leadership? Findings from two decades of scholarship. Review of educational research, 74 (3), 255-316. 